\title{
Design Analysis of Web-Based Employee Information System in Office of Technical Implementation Unit of Education Department
}

\author{
B. Ayshwarya, Adromi Yansyah, Phong Thanh Nguyen, K. Shankar, Wahidah Hashim, Satria \\ Abadi, Irina N. Odarich, Andino Maseleno
}

\begin{abstract}
KUPT Education Agency of Gunung Alip Sub-District is institution that handles education of elementary/kindergarten level in Gunung Alip Sub-District and all employees in KUPT Education Agency. KUPT Education Agency of Gunung Alip Sub-District in maintaining administration manually. Therefore Information System is needed to can help manage administration, especially personnel, quickly and easily. In making this information system the author used the waterfall method, Website programming. The resulting information system is expected to be used to manage employee data at the KUPT Education Office in Gunung Alip Sub-District.
\end{abstract}

Index Terms: Information system, education, web-based, web programming.

\section{INTRODUCTION}

\section{A. Background}

Nowadays, the development of information technology systems is very rapid [1-5]. Information technology system is usually applied in organizations that are carried out by using computer as a primary device in helping achieve the goals of organizations, companies and agencies concerned [6-9]. To get effective and efficient work results, organization must develop an information technology system that allows people to have the opportunity to interact and utilize these technology systems to help achieve their goals [10-13]. Employee affair information systems in Lampung Province is still mostly carried out using a manual implementation system in processing data. Based on the research conducted, the management of the employee affair administration at KUPT Gunung Alip Sub-District Education Agency has used computers as a work aid in administration management but it is only limited in typing data and reports. The system

Revised Manuscript Received on July 22, 2019.

B. Ayshwarya, Department of Computer Science, Kristu Jayanti College, Bangalore-560043, India.

Adromi Yansyah, Department of Information Systems, STMIK Pringsewu, Lampung, Indonesia.

Phong Thanh Nguyen, Department of Project Management, Ho Chi Minh City Open University (HCMCOU), Vietnam.

Wahidah Hashim, Institute of Informatics and Computing Energy, Universiti Tenaga Nasional, Malaysia.

K. Shankar, School of Computing, Kalasalingam Academy of Research and Education, Krishnankoil, India.

Satria Abadi, Institute Teknologi Sumatera, Lampung, Indonesia.

Irina N. Odarich, Togliatti State University, Russia.

Andino Maseleno, Institute of Informatics and Computing Energy, Universiti Tenaga Nasional, Malaysia. E-mail: andimaseleno@gmail.com that specifically handles or manages administrative data, especially employee affair data has not beent exist yet. So far the administration of the administration is still done manually so that a staff information system needs to be made at the KUPT Gunung Alip Sub-District Education Agency. It is expected that Education office and other agencies can integrate well with KUPT Gunung Alip Education Agency especially in the employee affair.

\section{B. Objectives}

Based on this research, there were some objectives :

a. Build an information system of employee administration management that can manage employee administration data a KUPT Gunung Alip Education Agency.

B. Can make it easier to provide report on the management of personnel administration in Gunung Alip sub-District.

\section{Benefit}

The benefits expected by researchers are as follows :

a. For researchers

1.To improve knowledge and insight through information system of employee administration management

2. To implement and develop knowledge obtained in collage.

b. Gunung Alip sub-distrcit Education agency.

1. As a consideration and input of KUPT Education Agency regarding information systems that can help resolve problems in managing employee administration

2. Providing convenience for the head of the administration division or section relating to the management of the administration.

\section{THEORETICAL BASE}

\section{A. Definition of System}

1. System is a conceptual structure composed of interconnected functions that work as an organic entity to achieve a desired outcome effectively and efficiently [14-17]. 2. System is logical and rational procedures to design a series of components that relates each other with the intention to function as a unit in an effort to achieve a predetermined goal [18-21].

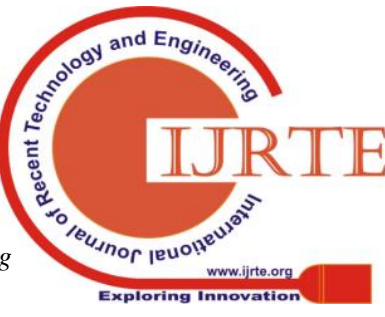




\section{B. Definition of Information}

1. Information is data that has been printed / processed into a very meaningful form to the recipient and is a true value or understood in the actions or current or further decision [22-25].

2. Information consisted of obtained and processed data or vice versa that was used for explanation, description or as basic in making prediction or making decision [26-29].

\section{Definition of Information}

Information System is a combination of human, facilities or technological tools, media, procedures and controls that intend to organize important communication networks [30-33], process certain and routine transactions, assist internal and external management and users and provide the basis for appropriate decision making [34-37].

Besides that, Information System is ways that are organized to collect, enter, process, and store data and ways that are organized to store, manage, control and report information in such a way so the organization can achieve its intended purpose [38-41].

\section{Definition of PHP}

PHP is a script-shaped language that is placed on a server and processed on the server. The results will be sent to the client, where the user uses the browser. PHP is known as a scripting language, which integrates with HTML tags, it can be executed on a server, and can be used to create dynamic web pages such as Active Server Pages (ASP) or Java Server Pages (JSP). PHP is an open source software. Well, this is what distinguishes ASP from PHP.

\section{E. Definition of MySQL}

MySQL is is a relationship database software (Relational Database Management System or RDBMS), like ORACLE, Postgresql, MS SQL, and others. MySQL AB calls its product the most popular open source database in the world. Based on research, the Web platform, and both for the open source and general categories, MySQL is the most widely used database. According to the company's developer, MySQL has been installed on about 3 million computers. Tens of hundreds of thousands of sites relying on MySQL work in day and night pumping data for their visitors.

\section{F. Definition of Web}

Web is a method for displaying information on the Internet, both in the form of text, figures, sounds and interactive videos and has the advantage of linking one document with another document (hypertext) that can be accessed through a browser [42-47]. While according to its definition, Web is a dissemination of information through the Internet [48-51]. Actually, between www (the world wide web) and the web are the same because most people abbreviate www as web only [52-57]. The web is an inseparable thing from the Internet world. Through the web, every internet user can access information on a website that is not only text, but also can be in the form of figure, sound, film, animation, etc [57-60]. Actually, the web is a collection of documents that is widely shared on several computer servers located in all places in the world and the boundaries become one network through a network called the Internet [61-65].

\section{G. Waterfall Method}

The method used in this study was Waterfall, this model is the most widely used model by software developers. In accordance with the name waterfall, the stages in this model are arranged in stages, each step in this model is done sequentially. The SDLC model used is waterfall.

\section{RESEARCH METHODOLOGY}

\section{A. Requirement Analysis}

This stage is analyzing the current system and analyzing the needs of the Information System [66-70] KUPT Gunung Ali Sub-District Education Agency.

\section{B. System Design}

This stage is illustrating the design of the employee affair information system that will be created at the KUPT Gunung Alip Sub-District Education Agency about what should be done and how to configure the appearance. This stage helps in specifying hardware and system requirements and defining the overall system architecture.

\section{Implementation}

In this stage programming was carried out [71-74]. Creating software at KUPT Gunung Alip Education Agency for employee affair information system that was broken down into small modules which will be combined in the next stage. In addition, at this stage an examination of the module was made, whether it has fulfilled the expected function or not.

\section{Integration \& Testing}

At this stage, the modules were combined and tested [75-78]. It was done to find out whether the software created is in accordance with the design and has no errors or not.

\section{E. Operation \& Maintenance}

This stage is the last stage in the waterfall model. The finished software was run and carried out the maintenance. Maintenance consisted of fixing errors that were not found in the previous stages. Improvement of system unit implementation and improvement of system services as new requirements.

\section{DESIGN ANALYSIS}

\section{A. Design Analysis}

System Design can be defined as illustration, design and sketch or maintenance from some separated elements as illustration, design and sketch or maintain from some separated elements into a unified function unity. Based on the results of the study the author tried to give a design that refers to the design of information systems at the staff of the KUPT Gunung Alip Sub-District Education Agency.

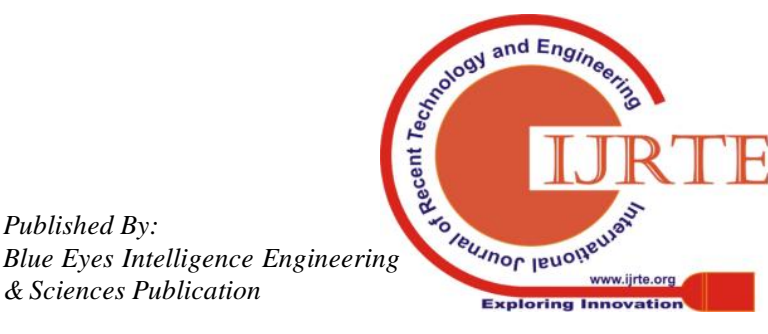




\section{B. Context Diagram}

Design of Civil Service Information System at KUPTD Education Gunung Alip Sub-district, Tanggamus District by creating a system flowchart that configurates how the personnel information system at the Office of the Technical Implementation Unit of the Gunung Alip Sub-District Agency in Tanggamus District. Before the computerized system and how the design of the development system continued by creating a diagram Context .

\section{WEBSITE IMPLEMENTATION}

Figure 1 shows Web Program. It is a full display page on the application program created at the KUPT Gunung Alip.

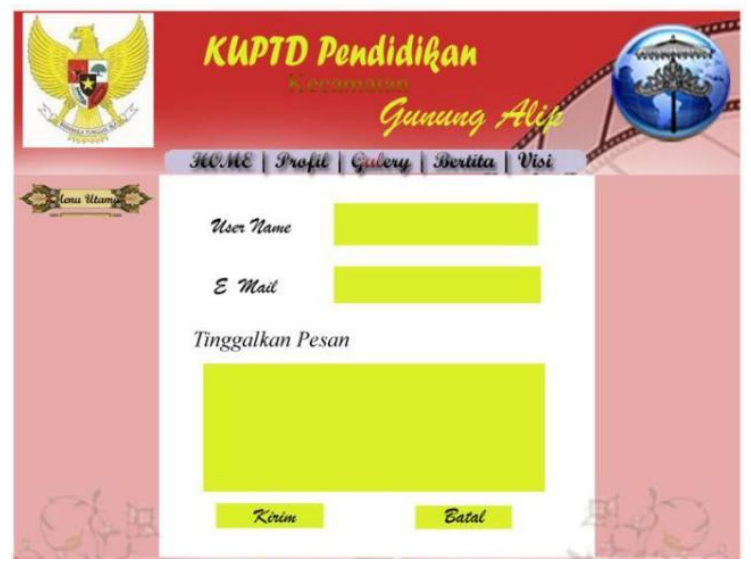

Figure 1. Web Program

Figure 2 shows header. Header is the main part in the application program that is the title / name of the application program at the Gunung Alip District Office on the website.

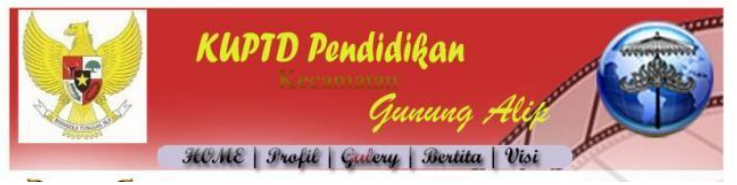

Figure 2. Header

Figure 3 shows content. This section is part of the content that discusses the KUPT Gunung Alip Sub-Distrcit.

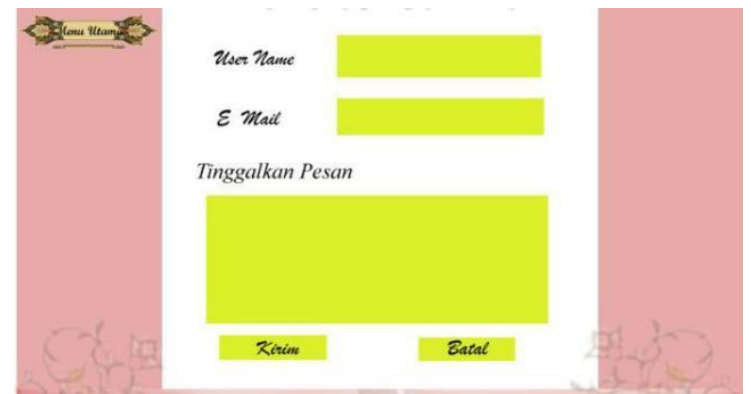

Figure 3. Content

Footer is the last part in the application program created. This section describes the identity and year of manufacture in the application program. User can directly access the application program at KUPT Gunung Alip Sub-District and can interact directly with the related data, especially in the employee affair.

\section{CONCLUSION}

Based on the results of the Website-Based Information System Design at the Office of the Technical Implementation Unit (KUPT) Gunung Alip Sub-District Education Office, Tanggamus District, it can be concluded :

1. With the existence of website application program it is expected that users can easily and quickly find out about information about Gunung Alip Sub-District KUPT Education Agency that is conducive and effective in improving the quality of education, especially in the employee affair .

2. KUPT Data can be monitored. KUPT data of the Education Office through the Website, so that the data / news that is still new can always be updated and summarized into the website.

3. Teacher and Civil Servants especially in the Gunung Alip Sub-District can always access information relating to employment policies

\section{REFERENCES}

[1]. Bochkareva, T. N., Drozdov, V. A., Akhmetshin, E. M., Prikhodko, A. N., Gorbenko, A. V., \& Zakieva, R. R. (2018). Improving Information and Technical Support of HR Management System in the Educational Establishment. Paper presented at the Proceedings of the $31 \mathrm{st}$ International Business Information Management Association Conference - Innovation Management and Education Excellence through Vision 2020, 3582-3589.

[2]. Akhmetshin, E., Ilyina, I., Kulibanova, V., \& Teor, T. (2019). Special aspects of master data-based integrated management of region reputation in modern IT environment. Paper presented at the IOP Conference Series: Materials Science and Engineering, 497(1) doi:10.1088/1757-899X/497/1/012022

[3]. Atova, A. Z., Sitdikov, F. F., \& Klychova, G. S. (2018). Reporting in the area of sustainable development with information technology application. Management Science Letters, 8(7), 785-794. doi:10.5267/j.msl.2018.5.008

[4]. Sychugov, A. A., Akhmetshin, E. M., Grishin, V. M., Shpakova, R. N., \& Plotnikov, A. V. (2019). Algorithm determine trust value to the distributed information systems elements. Journal of Mechanical Engineering Research and Developments, 42(2), 6-9. doi:10.26480/jmerd.02.2019.06.09.

[5]. Satria Abadi, Akmal Hawi, Akla, Ihsan Dacholfany, Miftachul Huda, Kamarul Shukri Mat Teh, Jaki Walidi, Wahidah Hashim, Andino Maseleno, Identification of Sundep, Leahopper and Fungus of Paddy by using Fuzzy SAW Method, International Journal of Pharmaceutical Research, Volume 11, Issue 1, January - March 2019.

[6]. Andino Maseleno, Miftachul Huda, Kamarul Azmi Jasmi,Bushrah Basiron, Ismail Mustari, Abdul Ghaffar Don, Roslee bin Ahmad, Hau-Kashyap Approach for Student's Level of Expertise, Egyptian Informatics Journal, Elsevier, Vol. 20, Issue 1, March 2019, pp. 27-32.

[7]. Liang Zhou, Hesam Kamyab, Aravindhan Surendar, Andino Maseleno, Aygul Z. Ibatova, Shreeshivadasan Chelliapan, Nima Karachi, Zohreh Parsaee, Novel Z-scheme composite $\mathrm{Ag} 2 \mathrm{CrO} 4 / \mathrm{NG} /$ polyimides as high performance nano catalyst for photoreduction of CO2: Design, fabrication, characterization and mechanism, Journal of Photochemistry and Photobiology A: Chemistry, Elsevier, Volume 368, 1 January 2019, pp 30-40.

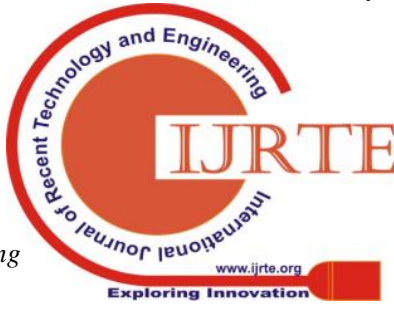


[8]. Muhamad Rusliyadi, Azaharaini bin $\mathrm{Hj}$. Mohd. Jamil, Marini Othman, Andino Maseleno, Ratna Tri Kumalasari, Agricultural Extension Policy, Agricultural Growth and Poverty Reduction in Indonesia, International Journal of Engineering and Technology (UAE), Vol. 7, No. 4, 2018, pp. $5539-5550$.

[9]. Gunawan Budiyanto, Sri Ipnuwati, Sayyid Azam Al Gifari, Miftachul Huda, Burhanuddin Jalal, Aliza Abdul Latif, Andino Maseleno, April Lia Hananto, Web based expert system for diagnosing disease pest on banana plant, International Journal of Engineering and Technology(UAE), Vol. 7, No. 4, 2018, pp. 4715-4721.

[10]. Elisabet Yunaeti Anggraeni, Pardimin, Ihsan Dacholfany, Akla, Miftachul Huda, Kamarul Shukri Mat Teh, Aminudin Hehsan, Juhazren Junaidi, Farahwahida Mohd Yusof, Hafiza Abas, Mohd Fauzi Abu Husin, Dina Apriani, Aliza Abdul Latif, Andino Maseleno, Modelling effectivenes of IS learning methodology with AHP method, International Journal of Engineering and Technology(UAE), Vol. 7, No. 4, 2018, pp. 4708-4714.

[11]. Aditya Mulawarman, Ajat Sudrajat, Nedi Hendri, Karnawi Kamar, Dedi Mulyadi, Gunawan Budiyanto, Miftachul Huda, Aliza Abdul Latif, Andino Maseleno, FMADM for determining superior commodity at agroindustry area, International Journal of Engineering and Technology(UAE), Vol. 7, No. 4, 2018, pp. 4667-4673.

[12]. Aprianti Putri Sujana, Andri Sahata Sitanggang, Andino Maseleno, Application of E-Transport through Android-Based Ticketing Applications, Journal of Advanced Research in Dynamical and Control Systems, Issue 13-Special Issue, 2018, pp. 1347-1356.

[13]. Pardimin, Apriadi, Widhiya Ninsiana, M. Ihsan Dacholfany, Karnawi Kamar, Kamarul Shukri Mat Teh, Miftachul Huda, April Lia Hananto, Muhammad Muslihudin, K. Shankar, Natalia V. Kamenez, Andino Maseleno, Developing Multimedia Application Model for Basic Mathematics Learning, Journal of Advanced Research in Dynamical and Control Systems, Issue 14-Special Issue, 2018, pp. 1347-1356

[14]. Natalia V. Kamenez, Olga Igorevna Vaganova, Zhanna Venediktovna Smirnova, Marina Nikolaevan Bulayeva, Ekaterina Andreevna Kuznetsova, Andino Maseleno, Experience of the use of electronic training in the educational process of the Russian higher educational institution, International Journal of Engineering and Technology(UAE), Vol. 7, No. 4, pp. 4085-4089, 2018.

[15]. Olga Igorevna Vaganova, Ludmila N. Zanfir, Zhanna Venediktovna Smirnova, Elena Aleksandrovna Chelnokova, Svetlana Nikolaevna Kaznacheeva, Andino Maseleno, On the linguistic training of future teachers of unlike specialties under the conditions of Russian professional education, International Journal of Engineering and Technology(UAE), Vol. 7, No. 4, pp. 4090-4095, 2018.

[16]. Olga Igorevna Vaganova, Natalia V. Kamenez, Vinnikova Irinia Sergeevna, Ekaterina Vladimirovna Vovk, Zhanna Venediktovna Smirnova, Andino Maseleno, Possibilities of information technologies to increase quality of educational services in Russia, International Journal of Engineering and Technology(UAE), Vol. 7, No. 4, pp. 4096-4102, 2018.

[17]. Zhanna Venediktovna Smirnova, Ludmila N. Zanfir, Olga Igorevna Vaganova, Natalia Vasilevna Bystrova, Nina Vladimirovna Frolova, Andino Maseleno, WorldSkills as means of improving quality of pedagogical staff training, International Journal of Engineering and Technology(UAE), Vol. 7, No. 4, pp. 4103-4108, 2018.

[18]. Abdul Hamid, Ajat Sudrajat, Razaleigh Muhamat Kawangit, Abdul Ghafar Don, Miftachul Huda, Burhanuddin Jalal, Wahyu Akbar, Azura Onn, Andino Maseleno, Determining basic food quality using SAW, International Journal of Engineering and Technology(UAE), Vol. 7, No. 4, pp. 3548-3555, 2018.

[19]. Noca Yolanda Sari, Miftachul Huda, Kamarul Shukri Mat Teh, Anggia Sari, Ramona Ramli, Andino Maseleno, Decision support system for determining chili plant using fuzzy multiple attribute decision making, International Journal of Engineering and Technology(UAE), Vol. 7, No. 4, pp. 3556-3562, 2018.
[20]. Oktafianto, Ajat Sudrajat Kawangit, Razaleigh Muhamat Kawangit, Abdul Ghafar Don, Miftachul Huda, Amel Dhea Saputri,Aliza Abdul Latif, Andino Maseleno, Determining housing location using weighted product, International Journal of Engineering and Technology(UAE), Vol. 7, No. 4, pp. 3563-3568, 2018.

[21]. Satria Abadi, Miftachul Huda, Kamarul Shukri Mat Teh, Zulkiflee Haron, Mohd. Nasir Ripin, Aminudin Hehsan, Shamsul Sarip, Muhamad Rafiqi Hehsan, Musfika Amrullah, Andino Maseleno, Hazard Level of Vehicle Smoke by Fuzzy Multiple Attribute Decision Making with Simple Additive Weighting Method, International Journal of Pharmaceutical Research, Vol. 10, Issue 4, 2018.

[22]. Fauzi, Miftachul Huda, Kamarul Shukri Mat Teh, Zulkiflee Haron, Mohd. Nasir Ripin, Aminudin Hehsan, Hafiza Abas, Muhamad Rafiq, July Irawan, Satria Abadi, Andino Maseleno, The Design of Fuzzy Expert System Implementation for Analyzing Transmissible Disease of Human, International Journal of Pharmaceutical Research, Vol. 10, Issue 4, 2018.

[23]. Mohamed Elhoseny, K. Shankar, S.K. Lakshmanaprabu, Andino Maseleno, N. Arunkumar, Hybrid Optimization with Cryptography Encryption for Medical Image Security in Internet of Things, Neural Computing and Applications, Springer, October 2018, pp. 1-15.

[24]. E. Laxmi Lydia, P. Krishna Kumar, K. Shankar, S.K. Lakshmanaprabu, R.M. Vidhyavathi, Andino Maseleno, Charismatic Document Clustering through Novel K-Means Non-negative Matrix Factorization (KNMF) Algorithm using Key Phrase Extraction, International Journal of Parallel Programming, Springer, 2018, pp. 1-19.

[25]. K. Shankar, S.K. Lakshmanaprabu, Deepak Gupta, Andino Maseleno, Victor Hugo C. De Albuquerque, Optimal feature-basedmulti-kernel SVM approach for thyroid disease classification, The Journal of Supercomputing, Springer, Vol. 74, no. 259, 2018, pp. 1-16.

[26]. M. Miftakul Amin, Adi Sutrisman, Deris Stiawan, Andino Maseleno, Design Restful WebService of National Population Database for supporting E-health interoperability service, Journal of Theoretical and Applied Information Technology, vol. 96, issue 15, 2018.

[27]. A.H. Motlagh, S.V. Klyuev, Aravindhan Surendar, Aygul Z. Ibatova, Andino Maseleno, Catalytic Gasification of Oil Sludge with Calcined Dolomite, Petroleum Science and Technology, Taylor and Francis, pp. 1-5, 2018.

[28]. Aravindhan Surendar, Alireza Bozorgian, Andino Maseleno, Lubov K. Ilyashenko, Meysam Najafi, Oxidation of Toxic Gases via Ge-B36N36 and Ge-C72 Nanocages as Potential Calaysts, Inorganic Chemistry Communications, Elsevier, Vol. 96, October 2018, pp. 206-210.

[29]. Abdolhamid Namdarian, Amin Goljanian Tabrizi, Andino Maseleno, Abdolkhaled Mohammadi, Seyyed Ebrahim Mossavifard, One step synthesis of rGO-Ni3S2 nano-cubes composite for high-performance supercapacitor electrodes, International Journal of Hydrogen Energy, Elsevier, vol. 43, Issue 37, 13 September 2018, pp.17780-17787.

[30]. Aravindhan Surendar, Lina G. Akhmetov, Lubov K. Ilyashenko, Andino Maseleno, Vahid Samavatian, Effect of thermal cycle loadings on mechanical properties and thermal conductivity of a porous lead-free solder joint, IEEE Transactions on Components, Packaging, and Manufacturing Technology, 2018, pp. 1769-1776.

[31]. Aravindhan Surendar, Vahid Samavatian, Andino Maseleno, Aygul Z. Ibatova, Majid Samavatian, Effect of solder layer thickness of thermo-mechanical reliability of a power electronic system, Journal of Material Science: Materials in Electronics, Springer, September 2018, Volume 29, Issue 17 , pp. $15249-15258$.

[32]. Majid Samavatian, Lubov K. Ilyashenko, Aravindhan Surendar, Andino Maseleno, Vahid Samavatian, Effect of System Design on Fatigue Life of Solder Joints in BGA Packages Under Vibration at Random Frequencies, Journal of Electronic Materials, November 2018, Volume 47, Issue 11, pp. 6781-6790.

[33]. Ilgar Javanshir, Andino 
Maseleno, Shahin Tasoujian, Majid Oveisi, Optimization of suspension system of heavy off-road vehicle for stability enhancement using integrated anti-roll bar and coiling spring mechanism, Journal of Central South University, September 2018, Volume 25, Issue 9, pp 2289-2298.

[34]. Andino Maseleno, Alicia Y.C. Tang, Moamin A. Mahmoud, Marini Othman, K. Shankar, Big Data and E-Learning in Education, International Journal of Computer Science and Network Security, 2018, Vol. 18, No. 5, pp. $171-174$

[35]. Muhammad Assahubulkahfi, Yahaya Md. Sam, Andino Maseleno, Miftachul Huda, LQR Tuning by Particle Swarm Optimization of Full Car Suspension System, International Journal of Engineering and Technology(UAE), Vol. 7, No. 2.13, 2018, pp. 328-331.

[36]. Dwi Kurniasih Kamarul Azmi Jasmi, Bushrah Basiron, Miftachul Huda, Andino Maseleno, The uses of fuzzy logic method for finding agriculture and livestock value of potential village, International Journal of Engineering and Technology(UAE), Vol. 7, No. 3, 2018, pp. 1091-1095

[37]. Hana Adela, Kamarul Azmi Jasmi, Bushrah Basiron, Miftachul Huda, Andino Maseleno, Selection of Dancer Member using Simple Additive Weighting, International Journal of Engineering and Technology(UAE), Vol. 7, No. 3, 2018, pp. 1096-1107.

[38]. Tri Susilowati, M. Ihsan Dacholfany, Sudirman Aminin, Afiful Ikhwan, Badlihisham Mohd. Nasir, Miftachul Huda, Adi Prasetyo, Andino Maseleno, Fiqih Satria, Sri Hartati, Wulandari, Getting Parents Involved in Child's School: Using Attendance Application System based on SMS Gateway, International Journal of Engineering and Technology(UAE), Vol. 7, No. 2.27, 2018, pp. 167-174.

[39]. Andino Maseleno, Alicia Y.C. Tang, Moamin A Mahmoud, Marini Othman, Suhendi Saputra, Muhamad Muslihudin, Fuzzy AHP Method to Determine Headache Types based on Symptoms, Investigacion Clinica, Vol. 58, No. 1, 2017.

[40]. Andino Maseleno, Miftachul Huda, Maragustam Siregar, Roslee Ahmad, Aminudin Hehsan, Zulkiflee Haroon, Moh Nasir Ripin, Siti Suhaila Ikhwani, Kamarul Azmi Jasmi, Combining the Previous Measure of Evidence to Educational Entrance Examination, Journal of Artificial Intelligence, Vol. 10, No. 3, pp. 85-90, 2017. ISSN 2077-2173. doi: 3923/jai.2017.85.90

[41]. Miftachul Huda, Andino Maseleno, Kamarul Azmi Jasmi, Ismail Mustari, Bushrah Basiron, Strengthening Interaction from Direct to Virtual Basis: Insights from Ethical and Professional Empowerment, International Journal of Applied Engineering Research, Vol. 12, No. 17, pp. 6901-6909, 2017. ISSN: 0973-4562.

[42]. Miftachul Huda, Andino Maseleno, Masitah Shahrill, Kamarul Azmi Jasmi, Ismail Mustari, Bushrah Basiron, Exploring Adaptive Teaching Competencies in Big Data Era, International Journal of Emerging Technologies in Learning, Vol. 12, No. 3, pp. 68-83, 2017. ISSN 1863-0383. doi: 10.3991/ijet.v12i03.6434.

[43]. Andino Maseleno, Glenn Hardaker, Noraisikin Sabani, Nabilah Suhaili, Data on multicultural education and diagnostic information profiling: Culture, learning styles and creativity, Data in Brief, Elsevier, Vol. 9, pp. 1048-1051, December 2016. doi: 10.1016/j.dib.2016.11.024.

[44]. Andino Maseleno, Md. Mahmud Hasan, Norjaidi Tuah, Charles Rangga Tabbu, Fuzzy Logic and Dempster-Shafer Theory to Predict The Risk of Highly Pathogenic Avian Influenza H5N1 Spreading, World Applied Science Journal, Vol. 34, No. 8, pp. 995-1003, 2016. ISSN: 1818-4952. doi: $10.5829 /$ idosi.wasj.2016.34.8.15688

[45]. Andino Maseleno, Glenn Hardaker, Malaria Detection using of Science and Technology, Vol. 38, No. 3, pp. 257-263, 2016.2 ISSN: 0125-3395. doi:10.14456/sjst-psu.2016.35

[46]. Andino Maseleno, Md. Mahmud Hasan, Muhammad Muslihudin, Tri Susilowati, Finding Kicking Range of Sepak Takraw Game: Fuzzy Logic and Dempster-Shafer Theory Approach, Indonesian Journal of Electrical Mathematical Theory of Evidence, Songklanakarin Journal

Engineering and Computer Science, Vol. 2, No. 1, pp. $187 \quad-\quad 193, \quad 2016 . \quad$ ISSN: 2502-4752. doi: 10.11591/ijeecs.v2.i1.pp187-193

[47]. Andino Maseleno, Md. Mahmud Hasan, Norjaidi Tuah, Fauzi, Muhammad Muslihudin, Fuzzy Logic Combined with Dempster-Shafer Theory for African Trypanosomiasis Spreading Prediction, Middle-East Journal of Scientific Research, Vol. 23, No. 9, pp. 2307 - 2317, 2015. ISSN: 1990-9233, doi: 10.5829/idosi.mejsr.2015.23.09.22600

[48]. Andino Maseleno, Md. Mahmud Hasan, Norjaidi Tuah, Combining Fuzzy Logic and Dempster-Shafer Theory, TELKOMNIKA, Vol. 16, No. 3, pp. 583-590, 2015. ISSN: 2302-404. doi: 10.11591/telkomnika.v16i3.9370

[49]. Bibi Rawiyah Mulung, Andino Maseleno, Proposed SMART Traffic Control Signal in Brunei Darussalam, TELKOMNIKA, Vol. 15, No. 2, pp. 277-282, 2015. ISSN: 2302-4046. doi: 10.11591/telkomnika.v15i2.8109

[50]. P. Uma Maheswari, P. Manickam, K. Sathesh Kumar, Andino Maseleno, K. Shankar, Bat optimization algorithm with fuzzy based PIT sharing (BF-PIT) algorithm for Named Data Networking (NDN), Journal of Intelligent \& Fuzzy Systems, IOS Press, pp. 1-8, 2019.

[51]. Grigory Olegovich Yarygin, Aleksandr Aleeksevich Korostelev, Rafis H. Mukhutdinov, Andino Maseleno, Elections and Russian Citizens Residing Overseas: Prospects for Internet Voting, International Journal of Recent Technology and Engineering (IJRTE), Vol. 7, Issue 6S5, pp. 52-57, 2019.

[52]. Larisa Akhunzhanovna Apanasyuk, Elena Vladimirovna Smirnova, Rafis H. Mukhutdinov, Andino Maseleno, The Problem of the Organization of Socio-Cultural Environment for Adaptation and Development of a Student-Migrant's Bilingual Identity in the Conditions of the Russian Higher Education, International Journal of Recent Technology and Engineering (IJRTE), Vol. 7, Issue 6S5, pp. 63-70, 2019.

[53]. Alla L. Busygina, Liliya A. Meteleva, Darya B. Shtrikova, Rafis H. Mukhutdinov, Andino Maseleno, Bases of Formation of Women's Professional Mentality in Russia, International Journal of Recent Technology and Engineering (IJRTE), Vol. 7, Issue 6S5, pp. 71-77, 2019.

[54]. Oleg N. Yarygin, Aleksandr A. Korostelev, Linar G. Akhmetov, Andino Maseleno, Modeling of Competence as a Tool of Goal Setting for Education in Modern Society, International Journal of Recent Technology and Engineering (IJRTE), Vol. 7, Issue 6S5, pp. 78-86, 2019.

[55]. Raven John, Aleksandr A. Korostelev, Oleg N. Yarygin, Rafis H. Mukhutdinov, Andino Maseleno, The Genesys and Base Concepts of Competentology, International Journal of Recent Technology and Engineering (IJRTE), Vol. 7, Issue 6S5, pp. 87-95, 2019.

[56]. Bogdanova Anna Vladimirovna, Aleksandr Alekseevich Korostelev, Rafis H. Mukhutdinov, Indira A. Shakirova, Andino Maseleno, Formulation of the Problem of Mathematical Modeling of Accommodation of Basic Stations of Cellular Communication in Residential Territories for Students of It-Directions of Preparation, International Journal of Recent Technology and Engineering (IJRTE), Vol. 7, Issue 6S5, pp. 96-100, 2019.

[57]. Bogdanova A. Vladimirovna, Aleksandr A. Korostelev, Olga L. Shepelyuk, Anna E. Rodionova, Irina N. Fardeeva, Andino Maseleno, Reengineering of Business Processes of the Higher School: Its Prerequisites, International Journal of Recent Technology and Engineering (IJRTE), Vol. 7, Issue 6S5, pp. 101-104, 2019.

[58]. Rustem R. Vakhitov, Anna E. Rodionova, Elena V. Smirnova, Rafis H. Mukhutdinov, Mariya I. Arzhakova, Andino Maseleno, Crisis of Higher Education in Russia, International Journal of Recent Technology and Engineering (IJRTE), Vol. 7, Issue 6S5, pp. 105-109, 2019.

[59]. Kuznetsov Sergey Vladimirovich, Magizov Rustem Robertovich, Radzevanovskaya Yuliya Viktorovna, Alexey V. Kuznetsov, Mukhametgaliev Iskandar Gabdulvaliyevich, Andino Maseleno, Public Anti-Corruption Control as a Mechanism to Counter Corruption in the Russian Federation, International Journal of Recent

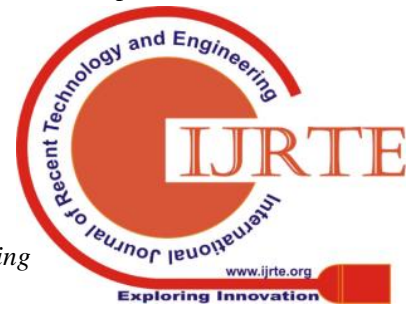


Technology and Engineering (IJRTE), Vol. 7, Issue 6S5, pp. 110-113, 2019.

[60]. R. Fenny Syafariani, Andri Sahata Sitanggang, Andino Maseleno, Application of Backend and Frontend Systems on Go-Baby Application in Bandung City, International Journal of Recent Technology and Engineering (IJRTE), Vol. 7, Issue 6S5, pp. 125-131, 2019.

[61]. Natalia L. Ivanova, Nikolay Ivanovich Sinyavsky, Alexey Valerievich Fursov, Oksana Petrovna Denisova, Andino Maseleno, Future Oil and Gas Students' Attitude to Healthy Lifestyle and Their Participation in the Implementation of Russian Physical Educational Complex «Ready for Labor and Defense» (Rld) Normatives, International Journal of Recent Technology and Engineering (IJRTE), Vol. 7, Issue 6S5, pp. 186-189, 2019.

[62]. Natalia P. Nikonova, Larisa N. Gorina, Andino Maseleno, Cooperation between the European Union and the Eurasian Union, International Journal of Recent Technology and Engineering (IJRTE), Vol. 7, Issue 6S5, pp. 201-203, 2019.

[63]. Natalie P. Nikonova, Larisa N. Gorina, Andino Maseleno, Inter-Regional Relationship Based on Geo Economics Requirements, International Journal of Recent Technology and Engineering (IJRTE), Vol. 7, Issue 6S5, pp. 204-206, 2019.

[64]. Fenny Syafariani R., Andri Sahata Sitanggang, Eko Yudhi Pramono, Wahidah Hashim, Andino Maseleno, Systems and Services Pattern Descriptions at Daycare, International Journal of Recent Technology and Engineering (IJRTE), Vol. 7, Issue 6S5, pp. 207-212, 2019.

[65]. Tri Susilowati, P. Manickam, G. Devika, K. Shankar, Latifah, Muhamad Muslihudin, Wahidah Hashim, Miftachul Huda, Aleksandr Aleeksevich Korostelev, Andino Maseleno, Decision Support System for Determining Lecturer Scholarships for Doctoral Study Using CBR (Case-Based Reasoning) Method, International Journal of Recent Technology and Engineering (IJRTE), 2019. pp. 3281-3290.

[66]. Muhamad Muslihudin, M. Ilayaraja, K. Sathesh Kumar, K. Shankar, Jauharotun Jamilah, Dita Novitasari, Miftachul Huda, Wahidah Hashim, Irina V. Rudenko, Andino Maseleno, Decision Support System in Kindergarten Selection using TOPSIS Method, International Journal of Recent Technology and Engineering (IJRTE), 2019. pp.3291-3298.

[67]. Muhamad Muslihudin, G. Devika, P. Manickam, K. Shankar, Dian Permana Putra, Eki Pramudia Sukarno Putra, Miftachul Huda, Wahidah Hashim, Oksana P. Denisova, Andino Maseleno, Expert System in Determining Baby Disease using Web Mobile-based Weighted Product Method, International Journal of Recent Technology and Engineering (IJRTE), 2019. pp.3299-3308.

[68]. Muhamad Muslihudin, K. Sathesh Kumar, M. Ilayaraja, K. Shankar, Lailaturrohmah, Dian Permana Putra, Wahidah Hashim, Andino Maseleno, Expert System in Determining the Quality of Nutmeg Breed using Website-Based Forward Chaining Methods, International Journal of Recent Technology and Engineering (IJRTE), 2019. pp.3309-3318.

[69]. Muhamad Muslihudin, S. Hemalatha, K. Shankar, Eswaran Perumal, Nofiyanti, Satria Abadi, Wahidah Hashim, Andino Maseleno, Application of Expert System for Determining Export Quality Pepper Seeds using Website-Based Forward Chaining Method, International Journal of Recent Technology and Engineering (IJRTE), 2019. pp. 3319-3329.

[70]. Muhamad Muslihudin, Rizky Purnama, Wahidah Hashim, Andino Maseleno, Selection of Temporary Landfill using Fuzzy Multiple Attribute, International Journal of Innovative Technology and Exploring Engineering, 2019. pp.598-604.

[71]. Muhamad Muslihudin, Siti Mukodimah, Erma Dwiyani, Trisnawati, Wahidah Hashim, Andino Maseleno, Fuzzy Logic Prediction of Dengue Hemorrhagic Fever Distribution in Pringsewu Region, International Journal of Innovative Technology and Exploring Engineering, 2019. pp.605-612.

[72]. S. Senthil, B. Ayshwarya, Prediction of Lung Cancer using Blue Whale Optimizer Algorithm with Neural Network Classifier, Journal of Advanced Research in Dynamical and Control Systems, Volume 11, 02-Special Issue, 2019. pp. 1737-1748.
[73]. Narges Bahrami, Sifeng Liu, Vadim Vitalievich Ponkratov, Phong Thanh Nguyen, Andino Maseleno, Stephen Berti, Novel Load Management for Renewable Generation Sources/Battery System through Cut Energy Expenditure and Generate Revenue, International Journal of Ambient Energy, Taylor and Francis Online, 2019.

[74]. Aravindhan Surendar, J. Muralidharan, Ali Dehghan Saee, Andino Maseleno, Aleksandr Alekseevich Rudenko, David Ros, Mathematical modelling of free convection in an ellipse-rectangular annulus filled with nanofluid using LBM, Thermal Science and Engineering Progress, Elsevier, 2019

[75]. Elena V. Smirnova, B. Ayshwarya, Phong Thanh Nguyen, Wahidah Hashim, Andino Maseleno, Using Shell Programs in Educational and Methodological Support for Learning Foreign Language, International Journal of Applied Exercise Physiology, Vol. 8 (2.1), 2019. pp. 1027-1032.

[76]. Inga E. Rakhimbaeva, Aleksandr A. Korostelev, Indira A. Shakirova, B. Ayshwarya, Phong Thanh Nguyen, Wahidah Hashim, Andino Maseleno, Integration of the Educational and Didactic Systems in the Training of Future Teachers, International Journal of Applied Exercise Physiology, Vol. 8 (2.1), 2019. pp. 1033-1038.

[77]. Alla L. Busygina, Elena M. Chertakova, Darya B. Shtrikova, B. Ayshwarya, Phong Thanh Nguyen, Wahidah Hashim, Andino Maseleno, Professional forms of Employment in the Russian Federation: Problems and Challenges, International Journal of Applied Exercise Physiology, Vol. 8 (2.1), 2019. pp. 1039-1045.

[78]. Olga I. Pugach, Andrei V. Ochepovsky, Wahidah Hashim, Andino Maseleno, B.Ayshwarya, Phong Thanh Nguyen, To the use of English Words When Learning Programming, Information Systems and Technologies, International Journal of Applied Exercise Physiology, Vol. 8 (2.1), 2019. pp. 1046-1051. 